\title{
Synchronization of Ovulation and Fixed-Time Insemination for Improvement of Conception Rate in Dairy Herds with Poor Estrus Detection Efficiency
}

\author{
Kyoji YAMADA, Tosihiko NAKAO ${ }^{1)}$ and Nagayosi MIHARA \\ Nakashunbetsu Veterinary Clinical Center, Nemuro District NOSAI, 3 Nakashunbetsu \\ Minami-machi Betsukai-chou, Notsuke-gun, Hokkaido 086-0652, and \\ ${ }^{1)}$ Department of Veterinary Obstetrics and Gynecology, Rakuno Gakuen University, \\ Ebetsu Hokkaido, 069-8501, Japan
}

\begin{abstract}
Objectives of this study were to examine effects of GnRH-PGF2 $\alpha-G n R H$ treatment and fixed-time AI (OVSYNCH) on the conception rate in Holstein-Friesian dairy herds with poor estrus detection efficiency in Eastern region of Hokkaido. In the first experiment ten cows, which were found to have normal ovarian cycle, were first injected intramuscularly with $100 \mu \mathrm{g}$ fertirelin acetate (an analog of GnRH), followed by an intramuscular injection of $25 \mathrm{mg}$ dinoprost (PGF2 $\alpha$ THAM) at an interval of 7 days. A second dose of fertirelin acetate was administered $48 \mathrm{~h}$ after the dinoprost injection. All cows were artificially inseminated (AI) $24 \mathrm{~h}$ after the second fertirelin injection. Milk progesterone profile and ultrasonography indicated that ovulation was synchronized in all 10 cows, and 70\% cows conceived. In the second experiment a total of 336 cows with postpartum anestrus were divided into two groups. A group of 185 cows were subjected for OVSYNCH, while the other group of 139 anestrus cows with functional corpus luteum were given $25 \mathrm{mg}$ dinoprost and inseminated artificially 3 days after the dinoprost treatment and 12 anestrus cows with inactive ovaries were injected with $100 \mu \mathrm{g}$ fertirelin acetate and inseminated artificially at heat and inserved as a control. Of 185 cows treated with OVSYNCH, 153 cows were inseminated artificially and 82 cows (53.6\%) conceived. A conception rate in control cows treated with dinoprost and bred 3 days later was $20.9 \%$. The OVSYNCH has been proved to be a useful tool for improving reproductive performance in dairy herds with a low estrus detection rate.
\end{abstract}

Key words: AI, Cow, GnRH, Ovulation, PGF2 $\alpha$.

(J. Reprod. Dev. 45: 51-55, 1999)

$\mathbf{T}$ he eastern region of Hokkaido is the biggest dairy farming area in Japan. Recently, the number of dairy cows per herd has been remarkably increased. However, techniques of feeding and breeding management have not been improved so far, and low conception rate due to poor estrus detection rate has become a serious problem. At present, although induction of estrus by means of

Accepted for publication: August 27, 1998

Correspondence: K. Yamada dinoprost administration has been widely utilized as powerful measures to assist in detecting estrus, the following problems have shown that estrous signs after injection of dinoprost are weak and therefore, appropriate timing of artificial insemination cannot be predicted. The period up to appearance of estrus after treatment also varies. In 1995, Pursley et al. [1] reported that fertility following GnRH-PGF2 $\alpha-G n R H$ method and fixed-time AI was satisfactorily high. Using the OVSYNCH is expected as a new breeding control 
method. In Japan, however, this method has not become common yet and no reports on this method have been published. The objectives of this study were to examine effects of OVSYNCH on the conception rate in dairy herds with poor estrus detection efficiency.

\section{Materials and Methods}

The experiments were carried out in 1996 from January to May. Used were 336 Holstein-Friesian dairy cows from 12 herds in eastern Hokkaido under a service of our Veterinary Clinical Center. The cows were not detected in estrus and not bred during a period of $40-150$ days after calving.

\section{OVSYNCH and fixed-time AI}

Dairy cows were first injected intramuscularly with $100 \mu \mathrm{g}$ of fertirelin acetate, followed by an intramuscularly injection of $25 \mathrm{mg}$ dinoprost at an interval of 7 days. A second dose of fertirelin acetate was administered $48 \mathrm{~h}$ after injection of the dinoprost. They were artificially inseminated $24 \mathrm{~h}$ after the second fertirelin acetate injection.

\section{The first experiment}

Ten cows showing no estrous sign were subjected for the OVSYNCH and changes in the ovary were observed using ultrasonography in the period to confirm the synchronization of ovulation. The dominant follicle is defined as the biggest diameter follicle. Milk progesterone levels were determined at a commercial clinical laboratory using a commercial available EIA kit (Ovucheck Milk P EIA kit, Cambridge Veterinary Science, UK). Inter and intra-assay coefficient of variations are known to be within $15 \%$ and $10 \%$, respectively. On day 32 after fixed-time AI, pregnancy was diagnosed using ultrasonography.

\section{The second experiment}

As a study group, 185 multiparous dairy cows were used and underwent the OVSYNCH, regardless of the phase, a follicular phase or luteal phase. Among 151 multiparous dairy cows in a control group, those in which inactive ovaries were intramuscularly injected with $100 \mu \mathrm{g}$ fertirelin acetate and underwent AI at heat. The dairy cows with corpus luteum were injected intramuscularly with $25 \mathrm{mg}$ dinoprost and underwent AI at the fixed date, 3 days after treatment, regardless of the presence or absence of estrus. Pregnancy was diagnosed by the rectal examination on day 40 after fixed-time $\mathrm{AI}$ and the first conception rates were compared.

Among the 185 dairy cows in study groups, the program was discontinued in 21 cows due to disease, culling the OVSYNCH and in 11 cows because estrous signs were observed after first injection of fertirelin acetate and AI was conducted.

\section{Statistical analysis}

The significance of differences between the control and the OVSYNCH groups were examined by $\chi^{2}$ analysis.

\section{Results}

\section{The first experiment}

The changes in the ovary following the hormone treatment are shown in Table 1. At the time of first fertirelin acetate injection, 5 cows were in the follicular phase and 5 in the luteal phase. In all the 5 cows in the follicular phase, dominant follicle was ovulated and luteinization of the ovarian follicle was observed at the time of injection of dinoprost 7 days later. In the 5 cows in the luteal phase, dominant follicle was luteinized in 2 cows, corpus luteum existing at the time of injection of fertirelin acetate remained in 1 cow, dominant follicle was ovulated and followed luteinization and corpus luteum remained as well in 2 cows. After injection of dinoprost, corpus luteum began to regress and dominant follicle was observed. No remarkable external estrous sign was observed in any animals during the period between injection of dinoprost and fixed-time AI. Ovulation was confirmed in all the animals on the next day of AI. Pregnancy was detected in the 7 cows by a pregnancy diagnosis conducted on day 32 after AI. The changes in progesterone level in milk in these cows are shown in Fig. 1. The progesterone levels were elevated around day 4 after injection of fertirelein acetate in both groups and the luteal phase was present at the time of injection of dinoprost. After injection of dinoprost, the progesterone levels remained at low at the times of second injection of fertirelin acetate and $\mathrm{AI}$ and began to rise around day 4 after AI. 
Table 1. The changes in ovary and conception rate in cows following OVSYNCH (First experiment)

\begin{tabular}{|c|c|c|c|c|c|c|}
\hline & \multirow[b]{2}{*}{ GnRH } & \multicolumn{3}{|c|}{ PGF $2 \alpha$} & \multicolumn{2}{|c|}{ conception } \\
\hline & & $\mathrm{F} \rightarrow \mathrm{CL}$ & $\mathrm{CL} \rightarrow \mathrm{CL}$ & $\begin{array}{c}\mathrm{F} \rightarrow \mathrm{CL} \\
\mathrm{CL} \rightarrow \mathrm{CL}\end{array}$ & $\begin{array}{l}\text { ovulation } \\
(\%)\end{array}$ & $\begin{array}{c}\text { rates } \\
(\%)\end{array}$ \\
\hline Follicular Phase & 5 & 5 & - & - & 100 & 60 \\
\hline Luteal Phase & 5 & 2 & 1 & 2 & 100 & 80 \\
\hline
\end{tabular}

F: ovarian follicle, CL: corpus luteum.

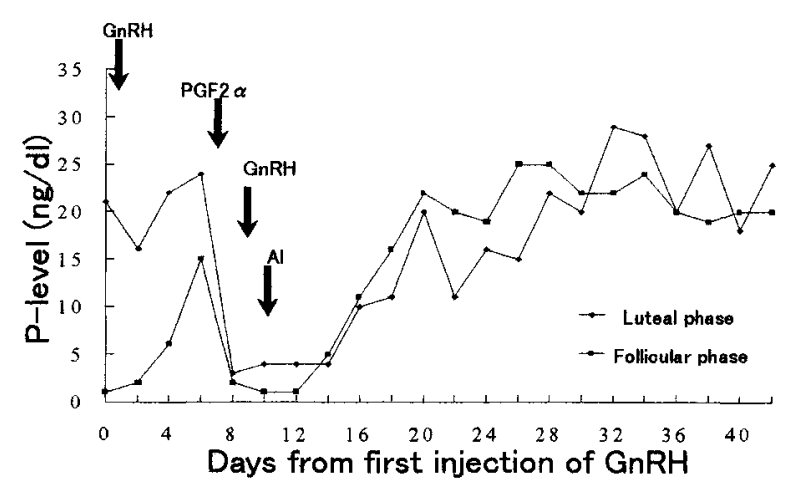

Fig. 1. The changes in progesterone concentrations in milk in cows in luteal phase or follicular phase after OVSYNCH.

\section{The second experiment}

The reproductive performance in the study group and the control groups is shown in Table 2. The conception rate after first insemination was $21.9 \%$ in the control group, while it was as high as $53.6 \%$ in the study group $(\mathrm{P}<0.05)$. The conception rate after first insemination was compared between the cows in which corpus luteum was confirmed at the time of first injection of fertirelin acetate in the study group and those in which corpus luteum was observed and dinoprost was injected in the control group. The conception rate was $59.1 \%$ in the study group, which was higher than $20.9 \%$ in the control group $(\mathrm{P}<0.05)$. Likewise, satisfactory conception rates were obtained in cows with inactive ovaries as well as in follicular phase after OVSYNCH.

\section{Discussion}

Although many researchers demonstrated that there were 2 or 3 follicular waves in the estrous cycle of cows [2-10], it is said that the interval from treatment to estrus differs depending on a phase of the follicular wave in which PGF2 $\alpha$ is injected [6]. However, it is difficult to judge a phase of follicular wave of the ovary by single rectal examination. Twagiramungu et al. [11-13] reported that a synchronization rate of estrus was improved by injection of GnRH 6 days before injection of PGF2 $\alpha$. Therefore, it is considered necessary not only to control regression of corpus luteum by means of PGF2 $\alpha$ but also to synchronize follicular waves by a combined use of $\mathrm{GnRH}$ in order to induce estrus at precise time. According to the ovulation synchronization method (OVSYNCH) reported by Pursley et al. [1, 5], injection of GnRH induces ovulation of ovarian follicle in various stages and leads formation of corpus luteum by LH and FSH released after GnRH injection, regardless of the phase of the ovarian cycle, and leads disappearance of FSH suppression ef-

Table 2. Reproductive performance in cows following OVSYNCH (Second experiment)

\begin{tabular}{|c|c|c|c|c|c|c|c|c|}
\hline & \multicolumn{2}{|c|}{ Luteal phase } & \multicolumn{2}{|c|}{ Inactive ovaries } & \multicolumn{2}{|c|}{ Follicular phase } & \multicolumn{2}{|c|}{ Total } \\
\hline & OV & $\mathrm{CO}$ & $\mathrm{OV}$ & $\mathrm{CO}$ & $\mathrm{OV}$ & $\mathrm{CO}$ & OV & $\mathrm{CO}$ \\
\hline No. of cows treated & 87 & 139 & 88 & 12 & 10 & - & 185 & 151 \\
\hline No. of cows inseminated & 66 & 139 & 77 & 12 & 10 & - & 153 & 151 \\
\hline No. of cows conceived & 39 & 29 & 37 & 4 & 6 & - & 82 & 33 \\
\hline Conception rate (\%) & $59.1^{\mathrm{a}}$ & $20.9^{b}$ & 48.1 & 33.3 & 60.0 & - & $53.6^{c}$ & $21.9^{\mathrm{d}}$ \\
\hline
\end{tabular}

OV: OVSYNCH, CO: Control. ab, cd: $\mathrm{P}<0.05$. 
fect of inhibin by ovulation. As a result, second FSH surge occurs and the growth of a new follicular wave is synchronized. Then, after injection of PGF2 $\alpha$ days following injection of GnRH, corpus luteum regresses and dominant follicle proceeds towards ovulation. Ovulation of this dominant follicle is synchronized $24-32 \mathrm{~h}$ later by second injection of GnRH. Therefore, it is considered that a high conception rate can be obtained by conducting AI $24 \mathrm{~h}$ after second injection of GnRH.

In the first experiment, the changes in the ovary were observed using ultrasonography. As a result, it was found that corpus luteum was formed by first injection of fertirelin acetate, corpus luteum regressed after injection of dinoprost, and dominant follicle was observed. Ovulation of dominant follicle was observed after second injection of fertirelin acetate in all the cows. A series of these changes agreed with those reported by Pursley et al. $[1,5]$. In addition, a conception rate as high as $70 \%$ was obtained. Therefore, it is considered possible to apply this method as a new breeding control method.

However, no remarkable estrous sign was observed in any animals on the day of AI. It has not been clarified why no estrous sign was observed. In the second experiment, the conception rate in OVSYNCH group (48.1\%) was higher than the control group (33.3\%) with inactive ovaries group. As the emergence of a dominant follicle after injected GnRH regardless of the phase of estrous cycle. But we need more works. So the number of cows is a few with the control group. And not synchronized causes are expected administrative and nutritional problems. The sufficiently high conception rate was obtained in the 153 dairy cows having undergone $\mathrm{AI}$ as compared with the control groups, and AI could be conducted certainly at the targeted timings in these cows. Consequently, the present method was more effective than the conventional one in which the presence of corpus luteum was confirmed by the rectal examination and then PGF2 $\alpha$ was injected. Stevenson et al. $[9,14]$ also reported that a conception rate of fixed-time AI after injection of PGF2 $\alpha$ was as low as $20-30 \%$, which agreed with the result of single PGF2 $\alpha$ injection in this study. Archbald et al. [15] and Lucy et al. [16] also stated that they did not recommend fixed-time AI after injection of PGF2 $\alpha$ for the purpose of improving conception rates.

Accurate detection of estrus is considered to be fundamental for the improvement of reproductive performance. In cows in which the time of AI after calving often delays due poor estrus detection, the OVSYNCH is considered beneficial, since fixed-time AI becomes possible, satisfactory conception rates can be obtained, and no rectal examination is required during this period. Consequently, the OVSYNCH has been proved to be a useful tool for improving reproductive performance in dairy herds with a low estrus detection rate.

\section{Acknowledgements}

We are grateful to the dairy farms and all the members of Nakashunbetsu Veterinary Clinical Center of Nemuro district NOSAI for their understanding and cooperation.

\section{References}

1. Pursley JR, Mee MO, Wiltbank MC. Synchronization of ovulation in dairy cows using PGF2 $\alpha$ and GnRH. Theriogenology 1995; 44: 915-923.

2. Adams GP, Matteri RL, Kastelic JP, Ko JCH, Ginther OJ. Association between surges of folliclestimulating hormone and the emergence of follicular waves in heifers. J Reprod Fert 1992; 94: 177-188.

3. Ginther OJ, Kastelic JP, Knopf L. Composition and characteristics of follicular waves during the bovine estrous cycle. Anim Reprod Sci 1989; 20: 187200.

4. Ireland JJ, Roche JF. Development of nonovulatory antral follicles in heifers: Changes in steroids in follicular fluid and receptors for gonadotropins. Endocrinology 1983; 112: 150-156.

5. Pursley JR, Stevenson JS, Minton JE. Ovarian follicular waves in dairy cows after administration of Gonadotropin-Releasing Hormone at estrus. J Dairy Sci 1993; 76: 2548-2560.

6. Roche JF, Mihm M, Diskin MG. Physiology and practice of induction and control of oestrus in cattle. Proc. 19th World Buiatrics Congress; 1996; Edinburgh. 157-163.

7. Savio JD, Keenan L, Boland MP, Roche JF. Pattern of growth of dominant follicles during the 
oestrous cycle of heifers. J Reprod Fert 1988; 83: 663671.

8. Sirois J, Fortune JE. Ovarian follicular dynamics during the estrous cycle in heifers monitored by real-time ultrasonography. Biol Reprod 1988; 39: 308-317.

9. Stevenson JS, Mee MO, Stewart RE. Conception rates and calving intervals after prostaglandin F2 $\alpha$ or prebreeding Progesterone in dairy cows. J Dairy Sci 1989; 72: 208-218.

10. Sunderland SJ, Crowe MA, Boland MP, Roche JF, Ireland JJ. Selection,dominance and atresia of follicles during the oestrous cycle of heifers. J Reprod Fert 1994; 101: 547-555.

11. Twagiramungu H, Guilbault LA, Dufour JJ. Synchronization of ovarian follicular waves with a Gonadotropin-Releasing Hormone agonist to increase the precision of estrus in cattle. A Review: J Anim Sci 1995; 73: 3141-3151.

12. Twagiramungu $\mathbf{H}$, Guilbault LA, Proulx J, Villeneuve P, Dufour JJ. Influence of an agonist of Gonadotropin-Releasing Hormone (Buserelin) on estrus synchronization and fertility in beef cows. J Anim Sci 1992; 70: 1904-1910.

13. Twagiramungu H, Guilbault LA, Proulx J, Dofour JJ. Synchronization of estrus and fertility in beef cattle with two injections of BUSERELIN and Prostaglandin. Theriogenology 1992; 38: 1131-1144.

14. Stevenson JS, Lucy MC, Call EP. Failure of timed insemination and associated luteal function in dairy cattle after two injections of Prostaglandin F2-alpha. Theriogenology 1987; 28: 937-946.

15. Archbald LF, Tran T, Massey R, Klapstein E. Conception rates in dairy cows after timedinsemination and simultaneous treatment with Gonadotrophin Releasing Hormone and/or Prostaglandin F2 alpha. Theriogenology 1992; 37: 723-731.

16. Lucy M, Stevenson JS, Call EP. Controlling first service and calving interval by Prostaglandin F $2 \alpha$, Gonadotropin-Releasing Hormone, and timed insemination. J Dairy Sci 1986; 69: 2186-2194. 